\title{
Phytochemical Characterization of Three Plants and Their Antisickling Activity in the Management of Sickle Cell Disease
}

\author{
Tatiana Kangah Mireille Kplé1, Joel Akakpo-Akue ${ }^{1}$, Julien Koffi Golly², Yvette Fofie ${ }^{3}$, \\ Marcel Gnamien Ahon', Mattieu Adou Kra1', Ibrahime Sanogo4, \\ Antoinette Chiayé C. Yapo-Crezoit ${ }^{2}$
}

\footnotetext{
${ }^{1}$ Laboratory of Biology and Health, UFR Biosciences, Université Félix Houphouët-Boigny (UFHB), Abidjan, Côte d'Ivoire ${ }^{2}$ Immunity Biology Center, Institut Pasteur de Côte d'Ivoire, Abidjan, Côte d'Ivoire

${ }^{3}$ UFR of Pharmaceutical and Biological Sciences, Université Félix Houphouët-Boigny (UFHB), Abidjan, Côte d'Ivoire ${ }^{4}$ Clinical Haematology Department, University Hospital of Yopougon, Abidjan, Côte d'Ivoire

Email: tatianakangah1@gmail.com
}

How to cite this paper: Kplé, T.K.M., Akakpo-Akue, J., Golly, J.K., Fofie, Y., Ahon, M.G., Kra, M.A., Sanogo, I. and Yapo-Crezoit, A.C.C. (2020) Phytochemical Characterization of Three Plants and Their Antisickling Activity in the Management of Sickle Cell Disease. Journal of Biosciences and Medicines, 8, $100-112$.

https://doi.org/10.4236/jbm.2020.86010

Received: April 26, 2020

Accepted: June 2, 2020

Published: June 5, 2020

Copyright ( 2020 by author(s) and Scientific Research Publishing Inc. This work is licensed under the Creative Commons Attribution International License (CC BY 4.0).

http://creativecommons.org/licenses/by/4.0/ (c) (i) Open Access

\begin{abstract}
Natural plant products have been used by the population of the south-eastern part of Côte d'Ivoire in the management of sickle cell anemia. This study was aimed at investigating the antisickling activity of the hydro-ethanolic extract of a combination of the leaves of J. secunda, J. gossypiifolia and $P$. nigrescens. These three plants species were used in the Ivorian traditional herbal medicine. Preliminary phytochemistry was carried out using standard methods. As for the sickling reversal test, the $\mathrm{Hb}$ SS blood sickling was induced with $2 \%$ sodium metabisulfite. After 120 minutes of incubation, the plant extract was added. Every 30 minutes for a period of 120 minutes, a drop of the prepared solution was observed at $(40 \times)$ magnification and the percentage of reversion calculated. The phytochemical analysis revealed the presence of Alkaloids, Flavonoids, Polyphenols, Catechic Tannins, Sterols and Polyterpenes. The results of the reversal test showed that the percentage of sickling reversal effect of the combination of the plants $\left(75.00 \pm 4.33^{\mathrm{b}, \mathrm{c}}\right)$ was highly superior than the negative control $\left(10.17 \pm 0.55^{\mathrm{d}}\right)$ but was significantly $(\mathrm{p}<0.05)$ the same as the percentage of the individual plant ( $J$. secunda: $83.50 \pm 2.33^{\mathrm{a}} ; J$. gossypiifolia: $78.00 \pm 3.67^{\mathrm{b}, \mathrm{c}}$ and P. nigrescens. $\left.77.83 \pm 2.89^{\mathrm{b}, \mathrm{c}}\right)$ and the positive control $\left(80.66 \pm 2.22^{\mathrm{a}, \mathrm{b}}\right)$. From the results, the extracts J. secunda, J. gossypiifolia and $P$. nigrescens have shown to be therapeutically beneficial to the population. Their use is also justified in the management of sickle cell disease in the south-eastern part of Côte d'Ivoire.
\end{abstract}




\section{Keywords}

Sickle Cell Disease, Antisickling Activity, Hydro-Ethanolic Extract, J. gossypiifolia, $P$. nigrescens, J. secunda, Côte d'Ivoire

\section{Introduction}

Sickle cell disease (SCD), also known as sickle cell anemia, is an inherited hemoglobinopathy caused by a point mutation. This mutation leads to the substitution of glutamic acid by valine in position 6 within the beta chain of hemoglobin. Under low oxygen pressure conditions, the resulted hemoglobin ( $\mathrm{HbS}$ ) has its affinity for oxygen and its solubility altered. The decreased solubility leads to the polymerization and the precipitation of HbS. This situation causes the blood cells' sickling [1]. In the homozygous individual, the clinical manifestations of the sickle cell anemia are mostly due to hemolytic anemia and vaso-occlusive crises resulting in pain and vital organ damage [2] and serious frequent infections [3]. Usually, the most frequent infections associated with this disease have been due to Staphylococcus aureus, Salmonella sp. and Escherichia coli [4]. The production of the oxidative stress due to a large number of free radicals is also one of main characters of this pathology [5]. All the complications of this disease listed above are main causes of death of sickle cell patients [6]. Sickle cell disease is one of the most prevalent hereditary disorders with prominent morbidity and mortality [7]. Although the global prevalence is more than 5\% [8], the proportion rises from $9 \%$ to $16 \%$ in West Africa [9]. Indeed, sickle cell disease affects nearly 275,000 newborns each year, $85 \%$ of which occur in sub-Saharan Africa [10]. In Côte d'Ivoire, the extend of this disease results in a prevalence rate of more than $14 \%$, of which more than $2 \%$ are Homozygous HbSS who are suffering the most from the complications of the pathology [11]. Several treatment options have been considered to relieve patients from sickle cell disease. As a curative therapy, chemotherapy, gene therapy and bone marrow transplantation have been proposed. Although bone marrow transplantation and gene therapy provide satisfactory results [12], the problem of finding suitable donor, makes these highly specialized and expensive therapeutic approaches unavailable in most developing countries. As for the symptomatic treatment, the risks of infections related to transfusion and many pronounced side effects of chemical substances such as Hydroxyurea (HU); Erythropoietin, Tucaresol, CiklervitTM etc., constituted a major obstacle to this approach [13] [14]. As proposed therapies remain very expensive for most African populations, they have recourse to medicinal plants in order to sickle cell disease [15] [16] [17] [18]. As some studies have shown that Ivorian flora has a real therapeutic and nutritional potential that can be used to treat or prevent many diseases [19], herbal therapy might provide adequate treatment for sickle cell disease subjects [20]. Several Medicinal plants used in traditional medicine have been shown to contain antisickling 
principles in vitro [21] [22] [23] [24]. The present study was performed with the aim of studying the in vitro antisickling activity of the aqueous and ethanolic extracts of J. gossypiifolia, J. secunda and P. nigrescens three plants used by the traditional healers in South-eastern of Côte d'Ivoire. Two points have been targeted:

Identify the different chemical groups present in hydroethanolic extract from each plant and the combination of the three plants;

In vitro sickling reversal test of the hydroethanolic extract of each plant and the combination of the three plants.

\section{Materials and Methods}

\subsection{Collection and Preparation of Plant Materials}

The plant material was composed of the leaves of J. gossypiifolia, J. secunda and $P$. nigrescens. The leaves of these plant species were harvested in Abengourou in South-eastern Côte d'Ivoire. The identification of the plant material was carried out by Mr Assi Jean of the National Floristic Centre (CNF) of Felix Houphouet-Boigny University. These leaves were washed, cut and dried at laboratory temperature of $25^{\circ} \mathrm{C}$. After three weeks of drying, they were ground and reduced into fine powder using a Severin ${ }^{\circledR}$ grinder.

\section{Hydro-Ethanolic Extraction}

The extraction was carried out using [25] method. One hundred grams (100 g) of vegetable powder were dissolved in one litre of hydroethanolic $70 \%$. The mixture was then homogenized six times using a Severin ${ }^{\circledR}$ Blender. The resulting homogenate was wrung out in a square of white cotton fabric, then filtered three times on hydrophilic cotton and once on Whatman paper $(3 \mathrm{~mm})$. The filtrate was evaporated at $45^{\circ} \mathrm{C}$ using a venticell ${ }^{\circ}$ type. The resulting dry powder was the hydro-ethanol extract (HEE). A total of 4 extracts were obtained: HEE $(J g)$ for $J$. gossypiifolia leaves, HEE $(J s)$ for $J$. secunda leaves, HEE $(P n)$ for $P$. nigrescens and HEE $(M)$ leaves for a mixture of the leaves of the three plants under studied in a proportion of 1:1:1.

\subsection{Phytochemical Screening}

Major groups of secondary metabolites such as sterols, polyterpenes, alkaloids, tannins, polyphenols, flavonoids, quinones, and saponins were characterized by classical methods described by [26]. The details concerning the used reagents and the characteristic reactions of the chemical groups are in Table 1.

\subsection{Antisickling Activity}

\subsubsection{Inclusion Criteria}

Six (6) children and adolescents, between 4 and 18 years old, were selected from the Clinical Hematology Department of the Hospital and University Hospital Center (CHU) of Yopougon (Abidajn-Côte d'Ivoire). Blood samples were first characterized 
Table 1. Reagents and tests of characterization of the chemical groups.

\begin{tabular}{ccc}
\hline Secondary metabolites & Reagents & Reaction indicating that the test is positive \\
\hline alkaloids & Dragendorff & Precipitate or orange colouring \\
flavonoids & Cyanidine & Reddish-brown precipitate \\
polyphenols & Ferric chloride & Heat then pink-orange or purplished colouring \\
quinones & Bornstraegen & Blackish-blue or green \pm dark colouring \\
saponosides & Foam Test & Persistent foam, higher than 1cm \\
sterols and polyterpenes & Liebermann & Crimson or purple ring, changing blue then green \\
tanins & Stiasny & Catechic precipitate in large flakes \\
& & Gallic blue-black deep colouring \\
\hline
\end{tabular}

by haemoglobin electrophoresis in order to confirm their SS nature. All antisickling experiments were carried out with freshly collected blood. Blood samples were stored at $\pm 4^{\circ} \mathrm{C}$ in a refrigerator. Ethical clearance on the use of SS blood was strictly observed according to international rules [27].

\subsubsection{Sickling Reversal Test}

The method of [28] was used according to a protocol described by [29]. This method was used to assess the effect of the extracts studied on the reversal of sickle cell formation.

\subsubsection{Washing the Blood Sample and Induction of Sickle-Training}

Five (5) $\mathrm{mL}$ of blood sample was collected to a labelled tube containing ethylene diamine tetracetate (EDTA). These samples were placed in cooler containing cold accumulators and transported to a refrigerator at $4^{\circ} \mathrm{C}$ at IPCI's Immunology Laboratory. The blood sample was washed for five minutes at $3000 \mathrm{rpm}$ three times in a row to remove the supernatant. Fifty (50) $\mu \mathrm{L}$ of red blood cells were mixed with $50 \mu \mathrm{L}$ of a $2 \%$ sodium meta bisulfite solution to induce the blood cells sickling. The tube containing the mixture was sealed with paraffin. After 30, 60, 90, and 120 minutes, a drop of the mixture was observed under the microscope and the rate of sickle cells was determinate representing the values of the negative control.

\subsubsection{Reversibility Test}

Fifty (50) $\mu \mathrm{L}$ of each of the 4 extracts HEE $(J g)$, HEE $(J s)$, HEE $(P n)$ and HEE $(M)$ at different concentrations between 0.05 and $10 \mathrm{mg} / \mathrm{mL}$, were added to the previous solution, after an incubation of $120 \mathrm{~min}$. Phenylalanine was used as a positive control. The SQA Vision microscope readings were performed every 30 minutes up to 120 minutes.

The change in the percentage of residual sickle cells over time was given by the following relationship:

$$
\text { PRS }=\frac{\text { sickle cells average at } T_{X}}{\text { sickle cells average at } T_{0}}
$$

PRS = Percentage of residual sickle cells;

$$
T_{X}=0,30,60,90 \text { and } 120 \text { minutes ; } T_{0}=\text { temps initial. }
$$




\subsection{Statistical Analysis}

Experimental data were processed using ANOVA statistical tool. The data obtained were entered through Excel software and then statistically analyzed using the software STATISTICA version 7.1 (processing by ANOVA 1 factor). The averages and standard deviations of the analyzed parameters were categorized using the DUNCAN test at $5 \%$.

\section{Results and Discussion}

\subsection{Phytochemical Study}

Secondary metabolites identification in the studied plants revealed the presence of flavonoids, terpenoids, polyphenols, alkaloids and catechic tannins (Table 1). However, HEE $(P n)$ tested negative for the presence of flavonoids. HEE $(J g)$ was the only extract showing the presence of traces of quinones. But this presence was not revealed in HEE $(M)$ (Table 1). Although HEE $(P n)$ tested negative for the presence of flavonoids and HEE $(J g)$ showed the presence of traces of Quinones, HEE $(M)$ continued to show only the presence of the compounds listed above. These new results revealed that the compounds characterized in HEE $(\mathrm{gg})$, HEE $(J s)$, HEE $(P n)$ were found in HEE $(M)$. The results of this present study are similar to those of [30] [31] which showed that the hydro-alcoholic extract of $J$. secunda contained the chemical groups listed above. [32] confirmed their presence in the leaves of $P$. nigrescens. The phytochemical screening of $J$. gossypiifolia seeds, leaves and roots by [33] revealed the presence of the same compounds. In addition to the molecules revealed by the hydro ethanol extract, the work of [24] revealed the presence of saponins, quinonic substances and gallic tannins in the aqueous extract of the combination of the three plants. The absence of certain secondary metabolites is explained by the fact that ethanol $70 \%$ would not be the extracting solvent of all metabolites from the plant combination.

Several studies have shown the biological activities of certain compounds found in HEE $(M)$. All of these compounds are known for their physiological activities and medicinal properties. [34] has demonstrated that alkaloids, tannins and flavonoids groups of chemicals promote tissue regeneration, decrease the permeability of blood capillaries and strengthen their resistance to hemolysis. Also, their antioxidant properties have been highlighted in [35] work, the anti-inflammatory property in [36] paper, the antimicrobial activity in [37] and [38] study. Among these compounds polyphenols and their derivatives have been cited as having antisickling activity [39]. The presence of sterols and polyterpenes, polyphenols, flavonoids, Catechic tannins and alkaloids could explain partially their use in traditional medicine (Table 2).

\subsection{Reversal Test}

Figure 1 shows the result of the red blood cell count in contact with sodium meta bisulfite as a function of time. This figure shows that the Sickling rate is maximal (100\%) after two hours $(2 \mathrm{~h})$. This Sickling is a function of time. 
Table 2. Tri-phytochemicals of individual plants and plant combinations.

\begin{tabular}{ccccc}
\hline $\begin{array}{c}\text { Plants } \\
\text { Metabolites }\end{array}$ & HEE $(J s)$ & HEE $(P n)$ & HEE $(J g)$ & HEE $(M)$ \\
sterols/polyterpenes & + & + & + & + \\
polyphenols & + & + & + & + \\
flavonoids & + & + & + & + \\
catechic tannins & + & - & + & - \\
gallic tannins & - & - & + & + \\
quinones & - & + & + & - \\
alcaloids & + & - & + \\
saponines & - & + & + \\
\hline
\end{tabular}

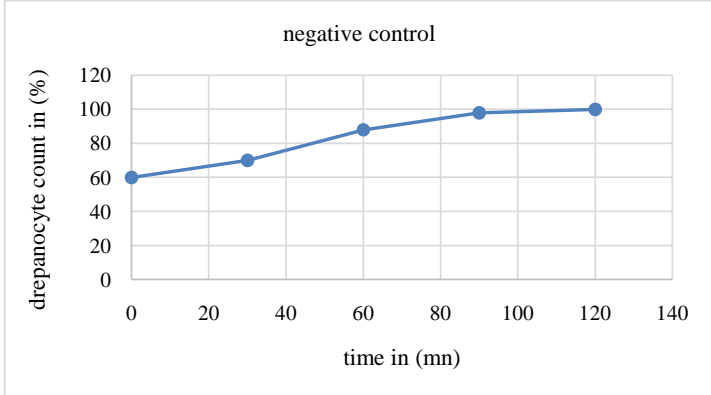

Figure 1. Percentage of red blood cells sickling in the presence of meta bisulfite of sodium $2 \%$ as a function of time.

The action of $2 \%$ sodium meta bisulfite on the blood resulted in erythrocyte disease. The sickle cell effect rate of $80 \%$ of HbSS blood cells after one hour is corroborated by the work of [39]. Moreover, this study showed that the formation of sickle cell disease is not an instantaneous phenomenon, it occurs over a certain period of time. Indeed, the polymerization that leads to sickle cell disease is preceded by the nucleation stage which consists in the formation of polymerization nuclei. This phase of nucleation corresponds to the "delay time" which can go from a few milliseconds to several days depending on the percentage of $\mathrm{HbS}$ and the age of the blood cells [40]. This could explain the increase in the rate of sickle cell disease over time.

\subsection{Reversibility of Antisickling by the Combination of Plants}

Table 3 shows that all the tested extracts of all plants have had a significant reversible effect on sickled cells compared to the negative control (10.17 \pm 0.55$)$. Compared to HEE $(J g)(78.00 \% \pm 3.67 \%)$, HEE $(P n)(77.83 \% \pm 2.89 \%)$, and HEE $(M)(75.00 \% \pm 4.33 \%)$ the reversible effect on sickled cells of HEE $(J s)(83.50 \% \pm$ $2.33 \%)$ had the higher reversible effect on sickled cells. This significant difference was not observed between $\operatorname{HEE}(J s)(83.50 \% \pm 2.33 \%)$ and the positive control represented by phenylalanine $(80.66 \% \pm 2.22 \%)$.

The difference between letters assigned to the percentage of reversibility shows 
statistically difference to $\mathrm{P}<0.05$ (ANOVA, DUNCAN). The presence of the letters $a, b, c, d$ shows whether or not there is a significant difference in the results of the plants and their combinations.

Figures 2-5 show the evolution of reversible effect of HEE $(M)$ on sickled cells according to its concentration. Indeed, HEE $(M)$ at different concentrations of $0.05 ; 0.5 ; 5$ and $10 \mathrm{mg} / \mathrm{mL}$ displayed a reversion rate of $50 \%, 63 \%, 65 \%$ and $75 \%$ respectively. This reversible effect on sickled cells has depended on the concentration of HEE $(M)$. This normalization of sickle cells occurs rapidly with a high rate in the first 30 minutes; then between 30 and 120 min the reversion is slow. This phenomenon is also well observed for phenylalanine.

Table 3. Percentage of sickle cells reversibility.

\begin{tabular}{cc}
\hline Hydroethanolic Extract & Reversibility (\%) \\
HEE $(J s)$ & $83.50 \pm 2.33^{\mathrm{a}}$ \\
HEE $(J g)$ & $78.00 \pm 3.67^{\mathrm{b}, \mathrm{c}}$ \\
HEE $(P n)$ & $77.83 \pm 2.89^{\mathrm{b}, \mathrm{c}}$ \\
HEE $(M)$ & $75.00 \pm 4.33^{\mathrm{b}, \mathrm{c}}$ \\
Positive control & $80.66 \pm 2.22^{\mathrm{a}, \mathrm{b}}$ \\
Negative Control & $10.17 \pm 0.55^{\mathrm{d}}$ \\
\hline
\end{tabular}

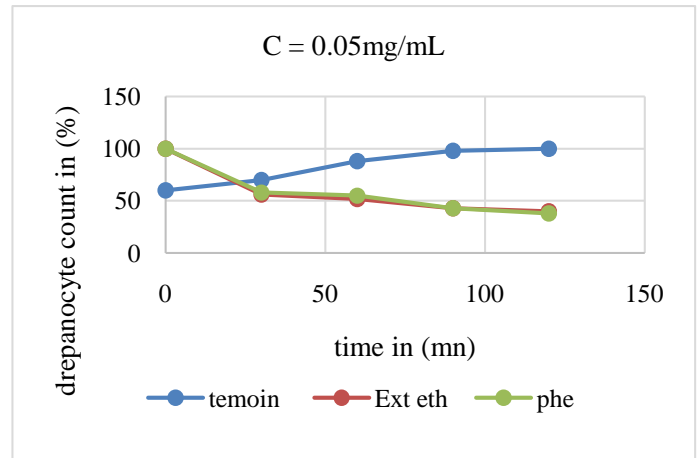

Figure 2. Percentage of the reversion rate in the presence of hydro-ethanolic extract at the concentration $0.05 \mathrm{mg} / \mathrm{mL}$.

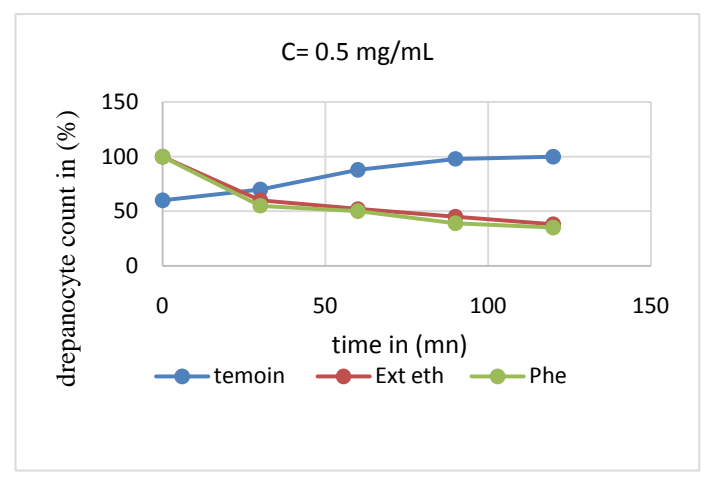

Figure 3. Percentage of the reversion rate in the presence of hydro-ethanolicextractat the concentration $0.5 \mathrm{mg} / \mathrm{mL}$. 


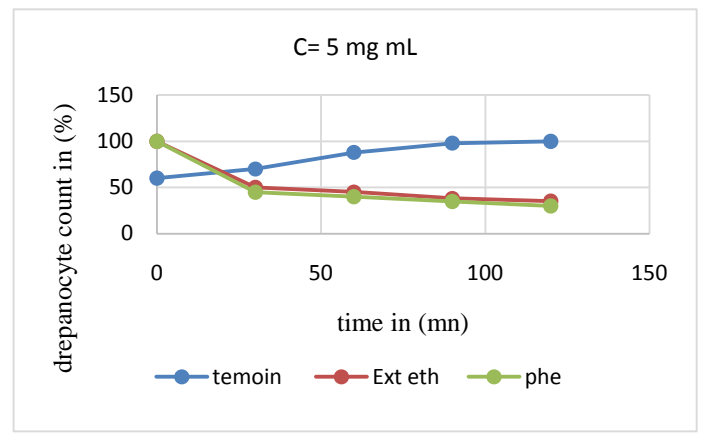

Figure 4. Percentage of the reversion rate in the presence of hydro-ethanolicextractat the concentration $5 \mathrm{mg} / \mathrm{mL}$.

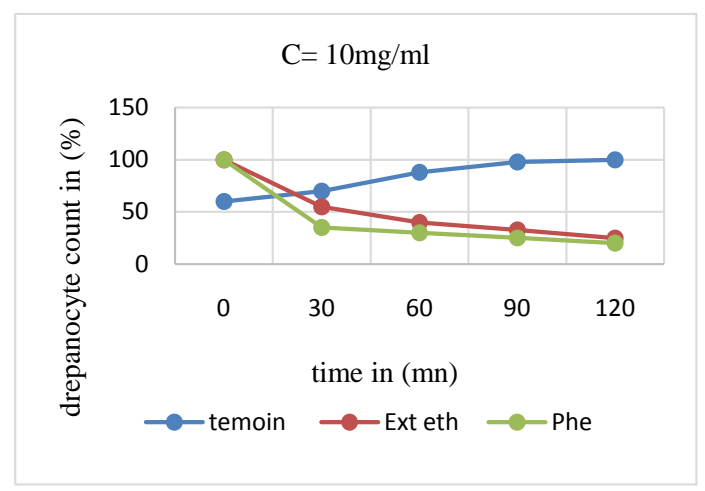

Figure 5. Percentage of the reversion rate in the presence of hydro-ethanolic extract at the concentration $10 \mathrm{mg} / \mathrm{mL}$.

It has been showed that HEE $(M)$ at $10 \mathrm{mg} / \mathrm{mL}$ has reversible effect of $75 \%$ on the sickled cells. Also, HEE $(M)$ at different concentrations of $0.05 ; 0.5 ; 5$ and 10 $\mathrm{mg} / \mathrm{mL}$ display reversible effect of $50 \%, 63 \%, 65 \%$ and $75 \%$ respectively. This increasing reversible effect depends on the concentrations of the plant extract. HEE $(J s)(83.50 \pm 2.33)$ was the most active extract while HEE $(M)$ display a reversible of $75.00 \% \pm 4.33 \%$. Anti-sickle cell activity of polar compounds such as phenolic compounds and phenylalanine has been reported in the literature [39]. Compared to the [24] study, the absence of certain metabolites did not prevent the reversibility of sickled cells up to $75 \%$ at the concentration of $10 \mathrm{mg} / \mathrm{mL}$. A similar result of $80 \%$ of normal cells was obtained by [39] by testing the metanolic extract of Leptadenia hastata roots on sickled cell. These results are comparable to those of [41] who showed that the activity of plant mixtures on the inhibition of erythrocytes sickling depended on the amount of plants used. These results are very significant in view of those obtained by other authors. Indeed [42] achieved 50\% inhibition with Niprisan ${ }^{\oplus}$, a plant-based anti-sickling cell product, while HEE $(M)$ at the $5 \mathrm{mg} / \mathrm{mL}$ concentration display reversible effect of sickled cells by $65 \%$. These results then justify the use of this combination of plants in the treatment of sickle cell disease in traditional environments. [43] worked on the activity of the hydro-ethanolic extract of $J$. secunda and J. curcas of which showed that these two plants have an antisickling activity that is due to the pres- 
ence of anthocyanins. Since J. curcas and J. gossypiifolia are from the same family, they could have the same secondary metabolites composition and this could explain the similarity of our results. As for [28], they showed that the leaves, roots and stem of $P$. nigrescens would have an inhibitory effect on hemolysis of erythrocytes. This would induce the stability of the erythrocytic membrane. Furthermore, based on the pathophysiology of sickle cell disease, sickled-shaped that is weak and not deformable would cause an increased blood's viscosity, resulting in vaso-occlusive complications [44]. Previous studies of some J. gossypiifolia activities have shown that this plant has anticoagulating activity [45] [46], antioxidant activity [46] and would act on renal lipid peroxidation [47]. Of all the above, it should be noted that HEE $(M)$ display an antisickling activity according to the concentrations tested and the solvents used. A variation in the proportions of the composition of these three plants could increase the antisickling activity of $\operatorname{HEE}(M)$.

\section{Conclusion}

This study was conducted to evaluate in vitro the reversible effect of hydroethanol extract from the combination of J. secunda, P. nigrescens and J. gossypiifolia. This work shows that hydro-alcolic extract at the concentration of $10 \mathrm{mg} / \mathrm{mL}$ has reversibility activity on red sickled cells. This activity might be due to phenolic compounds in this combination of plants as it has been shown to be one of the main components responsible for anti-sickling activity. In addition, this combination of plants could act in synergy because of the antisickling, anticoagulant, antioxidant and anti-hemolytic activity of each of them. Varying proportions of plants and the extraction solvent could improve the activity of the combination. Further studies will be needed to elucidate the nature of the active compounds, the mechanisms of action and perform the short, medium and long term toxicological study of these three plants.

\section{Acknowledgements}

The authors would like to thank the officials and staff of the Hematology Unit of the Yopougon University Hospital, the Pasteur Institute of Côte d'Ivoire, not to mention those of the Pharmacognosy Laboratory of the UFR of Pharmaceutical and Biological Sciences of Félix Houphouet Boigny University in Cocody for their availability and assistance in carrying out the work. There is also a thank you to all of these patients who have agreed to participate in this study.

\section{Conflicts of Interest}

The authors declare no conflicts of interest regarding the publication of this paper.

\section{References}

[1] Huynh-Moynot, S., Moynot, J.C., Commmandeur, D., Danguy Des Deserts, M., 
Montelescaut, E., Kenane, N. and Drouillard, I. (2011) Drepanocytose: Des aspects moléculaires à la pratique: A propos d'un cas et revue de la littérature. Annales de Biologie Clinique, 69, 679-684. https://doi.org/10.1684/abc.2011.0633

[2] Cotram, R.S., Kumar, V. and Collius, T. (1999) Robbins, Pathological Bases of Diseases. 6th Edition, W.B. Saunders Co., Philadelphia, 141, 611-613.

[3] Balgir, R.S. (2006) Do Tribal Communities Show an Inverse Relationship between Sickle Cell Disorders and Glucose-6-Phosphate Dehydrogenase Deficiency in Malaria Endemic Areas of Central-Eastern India? HOMO, 57, 163-176. https://doi.org/10.1016/j.jchb.2006.01.003

[4] Schmugge, M., Speer, O., Ozsahin, A.H. and Martin, G. (2008) La drépanocytose en Suisse, 1er partie: Physiopathologie, Clinique. Forum Médical Suisse, 8, 582-586. https://doi.org/10.4414/fms.2008.06560

[5] Sess, E.D., Carbonneau, M.A., Meite, M., Peuchant, E., Dumont, M.F., Receveur, M.C., Thomas, M.J., Perromat, A., Sangare, A., Le Bras, M. and Clerc, M. (1998) Markers of Lipid Peroxidation, Inflammatory Proteins and Plasma Tocopherols in Homozygotic and Heterozygotic Sickle Cell Anemia. Bulletin de la Société de Pathologie Exotique, 91, 238-241.

[6] Galacteros, F. (2015) La drépanocytose. European Journal of Obstetrics \& Gynecology and Reproductive Biology, 194, 183-188. https://doi.org/10.1016/j.ejogrb.2015.09.016

[7] Girot, R., Bégué, P. and Galacteros, F. (2003) La Drépanocytose. John Libbey \& Co., Paris.

[8] (WHO) World Health Organization (2010) Drépanocytose: Une stratégie pour la région africaine de l'OMS. Rapport du Directeur regional, $3 \mathrm{p}$.

[9] Ategbo, S., Kampatibe, N., Bodjona, H. and Assimadi, K. (1997) Hôpital et drépanocytose. In Drépanocytose et Santé publique, Vol. 1, Coéd. INSERM/CIE, Paris, 155.

[10] (IRD) Institut de Recherche pour le développement (2015) Sante-Afrique central la prevalence: La persistance de la prévalence du paludisme entretient la drépanocytose au Gabon.

[11] Sawadogo, D., Tolo-Dilkébié, A., Sangaré, M., Aguéhoundé, N., Kassi, H. and Latte, T. (2014) Influence of the Clinical Status on Stress Reticulocytes, CD36 and CD49d of SSFA2 Homozygous Sickle Cell Patients Followed in Abidjan. Advances in Hematology, 27, 38-60. https://doi.org/10.1155/2014/273860

[12] Misaki, W. (2008) Bone Marrow Transplantation (BMT) and Gene Replacement Therapy (GRT) in Sickle Cell Anemia. Nigerian Journal of Medicine, 17, 251-256. https://doi.org/10.4314/njm.v17i3.37390

[13] Charache, S., Terrin, M.L., Moore, R.D., Dover, G.J., Barton, F.B., Eckert, S.V., Mcmahon, R.P. and Bonds, D.R. (1995) Effect of Hydroxyurea on the Frequency of Painful Crises in Sickle Cell Anemia and the Investigators of the Multicenter Study of Hydroxyurea in Sickle Cell Anemia. The New England Journal of Medicine, 332, 1317-1322. https://doi.org/10.1056/NEJM199505183322001

[14] Mellouli, F. and Bejaoui, M. (2008) The Use of Hydroxyurea in Severe Forms of Sickle Cell Disease: Study of 47 Tunisian Paediatric Cases. Archives de Pédiatrie, 15, 24-28. https://doi.org/10.1016/j.arcped.2007.09.013

[15] Begue, P. and Castello-Herbreteau, B. (2001) La drépanocytose de l'enfant a l'adolescent, Prise en charge en 2001. Bulletin de la Société de Pathologie Exotique, 94, 85-89.

[16] Bernaudin, F. (1999) Resultats et indications actuelles de l'allogreffe de moelle dans 
la drepanocytose. Pathologie Biologie, 97, 59-64.

[17] Neuwinger, H.D. (2000) African Traditional Medicine. Mepharm Scientific Publisher, Stuttgart.

[18] Ngbolua, K.N., Rakotoarimanana, H., Rafatro, H., Urverg-Ratsimamanga, S., Mudogo, V., Mpiana, P.T. and Tshibangu, D.S.T. (2011) Comparative Antimalarial and Cytotoxic Activities of Two Vernonia Species: V. amygdalina from the Democratic Republic of Congo and $V$. cinerea Subsp Vialis Endemic to Madagascar. International Journal of Biological and Chemical Sciences, 5, 345-353. https://doi.org/10.4314/ijbcs.v5i1.68111

[19] Dro, B., Soro, D., Koné, M.W., Bakayoko, A. and Kamanzi, K. (2013) Evaluation de l'abondance de plantes médicinales utilisées en médecine traditionnelle dans le Nord de la Côte d'Ivoire. Journal of Animal et Plant Sciences, 17, 2631-2646. http://www.m.elewa.org/JAPS

[20] Ibrahim, H., Sani, F.S., Danladi, B.H. and Ahmadu, A.A. (2007) Phytochemical and Antisickling Studies of the Leaves of Hymenocardia acida Tul (Euphorbiaceae). Pakistan Journal of Biological Sciences, 10, 788-791.

https://doi.org/10.3923/pjbs.2007.788.791

[21] Elekwa, I., Monanu, O.M. and Anosike, O.E. (2005) Effects of Aqueous Extracts of Zanthoxylum macrophylla Roots on Membrane Stability of Human Erythrocytes of Different Genotypes. Nigerian Society for Experimental Biology. Biokemistri, 17, 7-12. http://www.bioline.org.br/bk https://doi.org/10.4314/biokem.v17i1.32582

[22] Mpiana, P.T., Misakabu, F.M., Yuma, P.M., Tshibangu, D.S.T., Ngbolua, K.N., Mwanyishay, C.L., Misengabu, N.M., Gbolo, Z.B. and Kayembe, J.S. (2014) Antisickling Activity and Physico-Chemical Stability of Anthocyanin Extracts from Ipomoea Batatas Leaves. Journal and Chemical Sciences, 9, 25-31.

[23] N'draman-Donou, E., Fofié, Y., Adjambri, E., Mélèdje, M.-F. and Sawadogo, D. (2015) Caractérisation et évaluation in Vitro de l'effet antifalcémiant des graines de Cajanus cajan (Fabacées) sur les drépanocytes à Abidjan Côte d'Ivoire. International Journal of Chemical Sciences, 9, 2300-2308. https://doi.org/10.4314/ijbcs.v9i5.4

[24] Akakpo-Akue, J., Kplé, T.K.M., Yapo-Crezoit, A., Fofié, Y., Kra, A.M., Tolo, D.A. and N'Guessan, J.D. (2018) In Vitro Antisickling Activity of the Aqueous Extract of a Combination of Three Plants: "Jatropha grossypiifolia, Justicia secunda and Parquetina nigrescens from East Côte d'Ivoire." IOSR Journal of Pharmacy and Biological Sciences, 13, 41-48. http://www.iosrjournals.org

[25] Zirihi, G., Kra, A.K.M. and Guede-Guina, F. (2003) Évaluation de l'activité antifongique de Microglossa pyrifolia (Lamarck) $O$. Kantze (Astéracée) PYMI sur la croissance in Vitro de Candida albicans. Revue de Médecine et pharmacie Afrique, 17, 11-18.

[26] Békro, Y.A., Békro, J.A., Boua, B.B., Tra, B.F. and Ehilé, E.E. (2007) Etude ethnobatanique et screening phytochimique de Caesalpinia benthamiana (Baill.) (Caesalpiniaceae). Sciences \& Nature, 4, 217-225.

[27] (WHO) World Health Organization (2002) World Health Report: Reducing Risks, Promoting Healthy Life. World Health Organization, Geneva.

[28] Emmel, V.E. (1933) A Red Cell Study of the Érythrocytes in Case of Severe Anemia with Elongated and Sickle and Shape Dred Blood Corpuscule. Archives of International Medicine, 7, 769-789.

[29] Imaga, N.O.A., Gbenle, G.O., Okochi, V.I., Adenekan, S.O., Edeoghon, S.O., Kehinde, M.O., Bamiro, S.B., Ajiboye, A. and Obinna, A. (2010) Antisickling and 
Toxicological Profiles of Leaf and Stem of Parquetina nigrescens L. Journal of Medicinal Plants Research, 4, 639-643.

[30] Gbenou, J.D., Tossou, R., Dansou, P., Fossou, M. and Moudachirou, M. (2006) Etude des propriétés antianémiques de justicia secunda vahl (acanthaceae) chez des rats de souche wistar. Sciences et Medecine, 14, 45-54.

[31] Mpiana, P.T., Ngbolua, K.N., Bokota, M.T., Kasonga, T.K., Atibu, E.K. and Mudogo, V. (2010) In Vitro Effects of Anthocyanins Extracts from Justicia secunda VAHL on the Solubility of Hemoglobin $S$ and Membrane Stability of Sickle Erythrocytes. Blood Transfusion, 8, 248-254.

[32] Sopeyin, A.O. and Ajayi, G.O. (2016) Pharmacognostic Study of Parquetina nigrescens (Afzel.) Bullock (Periplocaceae). International Journal of Pharmacognosy and Phytochemical Research, 8, 321-326.

[33] Abiodun, F., Tharcitus, C.O. and Nnena (2011) Isolation, Characterization and Antimicrobial Evaluation of Seed Extract of jatropha gossypifolia. Journal of Pure and Applied Sciences and Technology, 4, 1-4. https://doi.org/10.4314/bajopas.v4i2.1

[34] Railson, H., Michel, F.O., Aline, E.F.F., Priscila, H., Aguinaldo, J.D.N. and Maria, S.S.L. (2013) Protective Effect of Flavonoids against Reactive Oxygen Species Production in Sickle Cell Anemia Patients Treated with Hydroxyurea. Revista Brasileira Hematolgia Hemoterterapia, 35, 52-55. https://doi.org/10.5581/1516-8484.20130015

[35] Pandey, K.B. and Rizvi, S.I. (2009) Plant Polyphenols as Dietary Antioxidants in Human Health and Disease. Oxidative Medicine and Cellular Longevity, 2, 270-278. https://doi.org/10.4161/oxim.2.5.9498

[36] Gonzalez, R., Ballester, I., Lopez-Posadas, R., Suarez, M.D., Zarzuelo, A., MartinezAugustin, O. and Sanchez De Medina, F. (2011) Effects of Flavonoids and Other Polyphenols on Inflammation. Critical Reviews in Food Science and Nutrition, 51, 331-362. https://doi.org/10.1080/10408390903584094

[37] Daglia, M. (2012) Polyphenols as Antimicrobial Agents. Current Opinion in Biotechnology, 23, 174-181. https://doi.org/10.1016/j.copbio.2011.08.007

[38] Chávez, J.H., Leal, P.C., Yunes, R.A., Nunes, R.J., Barardi, C.R., Pinto, A.R., Simões, C.M. and Zanetti, C.R. (2006) Evaluation of Antiviral Activity of Phenolic Compounds and Derivatives against Rabies Virus. Veterinary Microbiology, 116, 53-59. https://doi.org/10.1016/j.vetmic.2006.03.019

[39] Seck, M., Cheikh, S., Gueye, P.M., Seck, I., Mbaye, D.D., Zhour, L., Rokhaya, S.G., Djibril, F., Mamadou, F. and Tandakha, N.D. (2015) Etude de l'activité antifalcémiante d'extraits de racines de Leptadenia hastata (Asclepiadacae). International Journal Biological and Chemical Sciences, 9, 1375-1383. https://doi.org/10.4314/ijbcs.v9i3.22

[40] Galactéros, F. (2001) Drépanocytose. Encyclop Orphanet, 1-5.

[41] Egunyomi, A., Moody, J.O. and Eletu, O.M. (2009) Antisickling Activities of Ethnomedicinal Plant Recipes Used for Management of Sickle Cell Anemia in Ibadan, Nigeria. African Journal of Biotechnology, 8, 20-25.

[42] Iyamu, E.W., Turner, E.A. and Asakura, T. (2002) In Vitro Effects of NIPRISAN (Nix-0699, a Naturally Occurring, Potent Antisickling Agent). British Journal of Haematology, 118, 337-343. https://doi.org/10.1046/j.1365-2141.2002.03593.x

[43] Ngbolua, K.N. (2012) Evaluation de l'activité anti-drépanocytaire et antipaludique de quelques taxons végétaux de la RD Congo et de Madagascar. Researchgate, 1-10.

[44] Zandecki, M. (2006) Hématologie biologique Faculté de Médecine CHU 49000 Angers France 4-8. 
[45] Oduola, T., Avwioro, G.O. and Ayanniyi, T.B. (2005) Suitability of the Leaf Extract of Jatropha gossypifolia as an Anticoagulant for Biochemical and Haematological Analyses. African Journal of Biotechnology, 4, 679-681.

https://doi.org/10.5897/AJB2005.000-3125

[46] Félix-Silva, J., Souza, T., Camara, R.B.G., Cabral, B., Silva-Júnior, A.A., Rebecchi, I.M.M., et al. (2014) In Vitro Anticoagulant and Antioxidant Activities of Jatropha gossypiifolia L. (Euphorbiaceae) Leaves Aiming Therapeutical Applications. BMC Complementary and Alternative Medicine, 14, 405.

https://doi.org/10.1186/1472-6882-14-405

[47] Khan, N., Sharma, S. and Sultana, S. (2004) Attenuation of Potassium Bromate-Induced Nephrotoxicity by Coumarin (1,2-Benzopyrone) in Wistar Rats: Chemoprevention against Free Radical-Mediated Renal Oxidative Stress and Tumor Promotion Response. Redox Report, 9, 19-28. https://doi.org/10.1179/135100004225003860 